\title{
The Impact of Land Use Change on The Groundwater Level in Suburban Area
}

\author{
Suhadi Purwantara \\ Department of Geography Education \\ Yogyakarta State University \\ Yogyakarta, Indonesia \\ Coresponding email: pur_geo@yahoo.com \\ Dyah Respati Suryo Sumunar \\ Department of Geography Education \\ Yogyakarta State University \\ Yogyakarta, Indonesia
}

\begin{abstract}
The long term goal of this research is to monitor the availability of groundwater in the next few decades. The specific aim of this study was to determine land use change impact on the groundwater level in Yogyakarta suburban areas in the last 20 years. This study used primary and secondary data obtained from land use map, groundwater depth data, rainfall data and temperature data. The data were analyzed using both qualitative and quantitative method. Changes in land use based on different land use map in decades. The changes of land use in decades were analyzed based on the maps. The changes of land use were analyzed to determine the land which optimally used as the settlement. In order to determine groundwater level, the temperature and rainfall data was used. The results of this study are expected to (1) illustrate the environmental impact on the community in suburban area; (2) prevent the water crisis.
\end{abstract}

Keywords-Land use, groundwater level, water crisis

\section{INTRODUCTION}

Since the last few decades, El Nino phenomenon has become a concern of humankind. Meteorology and climatology experts suggest that the El Nino phenomenon was able to be predicted in the last two decades. Previous experts in the field have not been able to analyze the phenomenon. Nowadays, the El Nino phenomenon has been observed and analyzed in many countries.

The worst El Nino occurred in Indonesia was in 2015 and 1997. El Nino had previously occurred in 1964, 1977 and 1982/1983. El Nino waves in Indonesia and Southeast Asia, in general, was characterized by a very long dry season. This long term dry season affects agriculture aspect. As the agrarian country, Indonesia relies on the availability of irrigation water as one of the most crucial aspects of farming.

Long drought results the reduction of the surface water significantly. Moreover, when the surface water decreases significantly, the ground water resource is also greatly reduced. It threatens the life of mankind. El Nino which comes frequently will impact on the arrival of droughts. The long term drought ultimately results the water crisis. It can happen because of the decreasing retaining and storing water media. The retaining and storing media are in the form of land and forest that serves as rainfall storage media. The reduction of rainfall storage media happens because of the changes of land use. The Land use broadly divided into two parts, namely the use of land for agricultural and non-agricultural purposes. The use of non-agricultural land is divided into urban and suburban area for residential, industrial, recreational space and so on (Arsyad, 2010). These changes occur as planned or unplanned and systematic or non-systematic projects.

Nowadays there are many green yards and fields into a new residential area with the compaction of the cement. The growth of five-star hotels on suburban area, Yogyakarta supports the reduction of the groundwater. Based on research conducted by Sudrajat, Syafri and Paripurno (2010), a decline in ground water level depth in Yogyakarta was 15 to $50 \mathrm{~cm}$ per year. This was alleged because of the excessive consumption of ground water by the hotels and the reduction of green space.

The green areas are mostly located in the region of Merapi's southern slopes, particularly the middle slope and the upper slopes have changed its function. In the lower slope, many settlements have grown significantly, while in the upper slopes, the forests change into the agricultural land. The above condition results in the amount of rainwater that seeped into the soil less and less, while the public awareness of the manufacturer of rainwater storage wells is limited (Purwantara, 2013, p. 43-58). The rapid development of settlements is one factor changes in land use, both on suburban areas of Yogyakarta namely Ngaglik, Ngemplak, Kalasan, Sleman, and some areas in Bantul. The urbanization in many regions has triggered scarcity of water, it was done because of the the improvement of population number affect the water demand.

Based on the problems above, the change the use of land in the suburb of Yogyakarta as well as the influence on soil water availability are discussion in this paper.

The problems are formulated as follow. 
- How does the land use change in the suburban areas of Yogyakarta?

- How does the ground water depth change in the suburban areas of Yogyakarta?

- How does the land use change impact on the soil water availability?

This research aims to determine:

- the changes in land use in the suburban area of Yogyakarta

- the ground water depth change in the suburban areas of Yogyakarta

- the influence of land use change on soil water availability.

\section{METHOD}

The data of this research were collected from the land use change, green area, soil, and water conservation data. This research was carried out in Yogyakarta suburban areas and focused on changes in land use and surface water depth.

This research is an environmental research study which focused on disasters, particularly about the water crisis caused by changes in land use by human beings with no regard to adverse effects.

This research is both qualitative and quantitative study. The primary and secondary data were analyzed. They were in the form of precipitation, temperature, depth of groundwater. To determine the amount of land use, land use data used should be at least 2 different times. Land use data can be obtained from an image through remote sensing technology. Remote sensing is the science for obtaining information and interpretation of the object by analyzing the data with the tool without direct contact (Lillesand and Keifer, 2007 in Sutanto, 2013 p. 5) Therefore, this study also used land use mapping in the form of aerial photograph and satellite imagery.

This study used a technique that includes interactive analysis namely data reduction, data presentation, and conclusion.In data reduction process, the raw materials were selected and analyzed. In this study, the numeric data then were categorized into some classification. Furthermore, in data presentation stage, the results then were concluded.

\section{FINDING AND DISCUSSION}

\section{A. Geological Conditions}

Geologically, the study area includes in Yogyakarta and Sleman Districts. Both are dominated with Mount Merapi. The geological formation is divided into volcanic rocks and sediment with volcanic deposits represent the majority of the total area. Volcanic materials from Mount Merapi that serves as a carrier layer of groundwater (aquifers), which has already broken down into volcanic sand material, then called new Merapi. Volcanic Material from new Merapi are divided into two units of geologic formation namely Sleman formation (dominated by fine pyroclastic deposits and tuff (a light, porous rock formed by consolidation of volcanic ash) in the lower area and Yogyakarta formation (dominated by the grained up volcanic sands and pebbles) at the upper area (McDonald, 1984). These formations serve as the main water carrier layer potential and aquifer system that called Merapi Aquifer System (SAM). The aquifer system flows constantly from north to south.

The type of soil in Sleman district is divided into litosol, regosol, grumosol, and Mediterranean. Mostly in Sleman area dominated by regosol soil types, while a small portion in the form of land Mediterranean, litosol, and grumusol. Some of its suburban form and cambisol latosol land, as well as in suburban areas on the border with the District Bantul call Merapi Aquifer System (SAM). The aquifer system constantly from north to south and administratively included in Sleman, Yogyakarta and Bantul.

\section{B. Hydrological Conditions}

The slope areas up to the foot of Merapi, there are many ravines. Some of the larger large rivers are Boyong, Code, Kuning, Gajahwong, and Winongo. Based on the rock bedding presented previously, this area has a very good aquifer. Merapi groundwater flows beneath the surface and moves towards a lower area to the south. Some are truncated by the buckling slope or cracks or fracture topology so that it appears in the form of springs. Some spring belts has been extensively studied, namely: Bebeng spring at an altitude of 1000 meters, Sleman-Cangkringan spring at an altitude of 500 meters, Ngaglik spring at an altitude of 300 meters, and Yogyakarta spring at an altitude of 130 meters. These springs have been used for daily consumption and irrigation.

\section{Climate}

Based on the average rainfall data for 10 years, the average rainfall was $1710 \mathrm{~mm}$. The number of wet season for ten years lasted about 63 months and dry season was 45 months. The 'build up' is the humid time of year between the wet and dry seasons. It lasted for 12 months.

Based on the rainfall level, the research areas are including in medium type. It can be seen that from November to May is the wet season. The mean of rainfall in was $195 \mathrm{~mm}$ in November; $261 \mathrm{~mm}$ in December; $269 \mathrm{~mm}$ in January; $284 \mathrm{~mm}$ in February; $208 \mathrm{~mm}$ in March; in April amounted to $204 \mathrm{~mm}$, and in May amounted to $119 \mathrm{~mm}$. In a year, the wet season occurs for seven months, the rest are humid and dry months. There was no regular humid season in a year based on the rainfall data, but based on the overall rainfall data in the past ten years, the amount of this season was 12 months. The number of dry months in a year based on the average rainfall was five months, but for ten years there were a number of 45 months. It concludes that the areas are categorized as medium, however the wet months is greater than the dry. The wet months with the rainfall above $200 \mathrm{~mm}$ was recorded in six months, ie from November to April. In May, the rainfall was only $119 \mathrm{~mm}$, in terms of the amount of rainfall is relatively moist. Based on the rainfall level, the supply of ground water comes from rain water should have been a draw. 


\section{The Land Use Changes}

Changes in land use into settlements happened rapidly. In 2003 , the large of the settlement area was $11.109375 \mathrm{~km}^{2}$ while in 2015 it turned into $14.33376 \mathrm{~km}^{2}$ therefore during 12 years, the settlement expansion occurs at $3.22425 \mathrm{~km}^{2}$.

\section{E. The Depth of Groundwater}

Ground water depth measured by wells, in suburban areas, has declined. The environment agency has observed the ground water depth since 2010, 2012, 2013, and 2014. From the observation, the average of ground water level has decreased, in terms of surface water. It can be seen from the following table.

TABLE 1. DEPTH WELL CHANGES IN YOGYAKARTA AND SURROUNDING AREAS

\begin{tabular}{|c|c|c|c|c|c|}
\hline No & Location & 2010 & 2012 & 2013 & 2014 \\
\hline 1 & Mrs.Mamik, Klitren Lor & 8.83 & 9.3 & 7.12 & 8.94 \\
\hline 2 & Public Health Center, DIY & 9.11 & 9.62 & 9.17 & 10.65 \\
\hline 3 & Cipta Karya Home & 9.5 & 9.98 & 9.58 & 9.8 \\
\hline 4 & $\begin{array}{l}\text { Gondokusuman Police } \\
\text { Station }\end{array}$ & - & 7.56 & 6.57 & 8.22 \\
\hline 5 & $\begin{array}{l}\text { Wiryo } \\
\text { Pawiro,Sosrodipuran }\end{array}$ & 11.7 & 12.39 & 11.93 & 11.57 \\
\hline 6 & Paryadi, Ngampilan & 11.3 & 13.15 & 12.38 & 13.01 \\
\hline 7 & Sisingamangaraja Mosque & 4.28 & 5.38 & 4.98 & 7.73 \\
\hline 8 & Bu Subur, MT Haryono & 5.6 & 5.12 & 4.83 & 5.6 \\
\hline 9 & Madiyono, Pramuka & 4.27 & 4.46 & 4.27 & 5.17 \\
\hline 10 & Sosro Suwondo, Veteran & 8,0 & 7.61 & 7.87 & 9.34 \\
\hline 11 & Komplek CPM Sentulrejo . & 3.16 & 3.23 & 3.02 & 4.24 \\
\hline 12 & Asrotun, Dongkelan & 2.24 & 2.91 & 2.84 & 3.45 \\
\hline 13 & $\begin{array}{l}\text { Panggungharjo District } \\
\text { Office }\end{array}$ & 1.42 & 1.87 & 1.74 & 2.35 \\
\hline 14 & Sewon District Office & 0.78 & 1.07 & 1.1 & 1.95 \\
\hline 15 & MITRA Ironmungery & 4.23 & 4 & 4.22 & 5.36 \\
\hline 16 & Henny, Imogiri Timur & 4.07 & 4.23 & 4.42 & 5.32 \\
\hline 17 & Diro Indah Wood Shop & 1.2 & 1.26 & 1.38 & 2.62 \\
\hline
\end{tabular}

\section{F. Suburban in the Northern Territory}

The depth of the wells also decreased since the rapid growth of hotels, shopping malls, apartments, and housing. Based on the depth of 20 well water samples, almost entire samples showed a significant decline in the depth of the well water level. However, the decline occurred mainly in areas where the water depth relatively deep over 6 meters. Some wells even only decreased when development takes place, but then gradually recovered. Some wells were located in the southern city of Yogyakarta, which has a relatively shallow water depth, which is less than 4 meters. Instead, most of the wells in the vicinity of hotels, malls, and apartments in the north of Yogyakarta all decreased significantly. In the area, the average well depth was over 8 meters.

For example around Tjokro and Edelweiss Hotel located in Jalan Gejayan, the average depth of the ground water level has decreased 2.0 to 2.30 meters. Moreover the ground water depth around Sejahtera Family Apartment has reached 2.9 meters. The wellsdepth near New Saphire Hotel (1996) Demangan, Hartono Mall (2013) Condongcatur, also have declined up to 4.0 meters.

\section{G. Suburban in the Southern Territory}

The data above contradicts with the hotels located on the southern ring road, as D'Omah Hotel Jalan Parangtritis km 8.5 and Ros Inn Hotel. A decrease occurred during the construction. The groundwater level was back to normal when the construction process completed. In this area, the groundwater relatively shallow. It is only about 1.3 to 4.0 meters. Based on the primary data, there is no change in the surface water depth.

Those data represent the population of groundwater located in Yogyakarta suburban. It appears that the northern suburban area has decreased dramatically, whereas the southern suburb was only a slight change even partially fixed. That's because the northern suburb is a recharge areas, ie areas which potential to incorporate rainwater. Things different happened in the southern suburb. In the south, with a depth of groundwater less than 3 meters, especially in the rainy season, most of the areas are discharge areas. In relation to the potential for groundwater, the suburban inhabitants have very shallow ground water. Conversely, northern suburb with a depth of groundwater for more than eight meters and a decrease in ground water level is very large, more than two meters, then it is not good for the quantity and quality of groundwater in the future.

TABLE 2. DEPTH WELLS CHANGE IN YOGYAKARTA SOUTH SUBURBAN AND SURROUNDING AREAS

\begin{tabular}{|l|l|r|r|r|}
\hline No & \multicolumn{1}{|c|}{ Hotel/Mall/Settlement } & Before & After & $\begin{array}{c}\text { Fluctu } \\
\text { ated }\end{array}$ \\
\hline 1 & The Edelweiss Hotel (2011) & 7,33 & 9,33 & -200 \\
\hline 2 & Grand Tjokro Hotel (2013) & 9,00 & 11,30 & -230 \\
\hline 3 & $\begin{array}{l}\text { Sejahtera Family Apart men } \\
(2009)\end{array}$ & 9,00 & 10,90 & -290 \\
\hline 4 & New Saphire Hotel (1996) & 7,00 & 7,94 & -194 \\
\hline 5 & The Victoria Hotel (2011) & 6,00 & 7,25 & -25 \\
\hline 6 & Indoluxe Maguwo (2014) & 5,30 & 5,84 & -54 \\
\hline 7 & Hartono Mall (2013) & 8,23 & 12,23 & -400 \\
\hline 8 & D'Omah Hotel & 1,4 & 1,4 & 0 \\
\hline 9 & Ros Inn Hotel & 3,6 & 3,6 & 0 \\
\hline
\end{tabular}

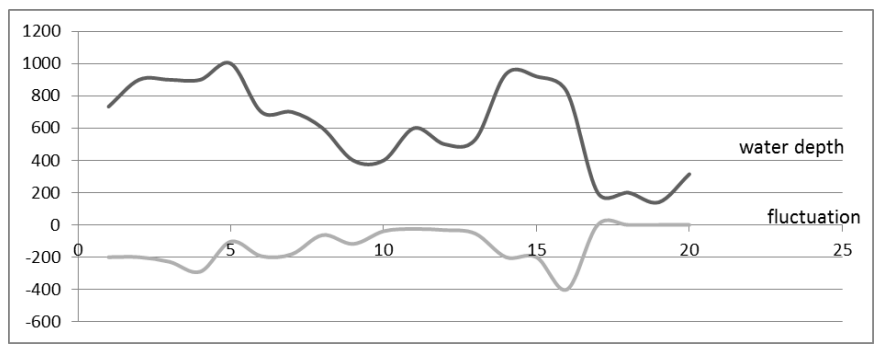

Fig. 1. The relation between the well water depth and the fluctuation

Based on the data, the decrease of the groundwater depth depends on the surface of the well water. The greater the depth of the well surface, the greater the decrease of ground water. Conversely the lower the depth of the well water surface, the smaller the changes. Based on two of these symptoms, associated with discharge and recharge area, the south Ringroad is discharged area, so that the ground water supply is very large. Instead, the North Ringroad are the recharge are that accelerate the reduction of the groundwater. It can be seen in figure1. 


\section{CONCLUSIONS AND SUGGESTIONS}

The unstoppable construction of hotels and settlements has changed the land use. The productive land use for agriculture needs has turned into the settlements, both for the location of businesses, hotels, shopping malls, as well as for housing residents. The increasing number of hotels, apartments, and shopping malls in Yogyakarta is resulting in the high demand of water. One of the most convenient sources of water that is taking ground water. The high demand of ground water affects the decrease of the groundwater level and also the possibility of deterioration in the quality of the ground water. The ground water in Sleman suburban has significantly decreased while the ground water in Bantul suburban has no or very slightly decreased.

\section{REFERENCES}

[1] Arsyad, Sitanala. 2010. Konservasi Tanah dan Air. Bogor: IPB Press

[2] Lillesand, T.M. and Keifer, R.W. 2007. Penginderaan Jauh dan Interpretasi Citra. Yogyakarta: UGM Press

[3] Sudrajat, A, Syafri, I and Paripurno, E.T. 2010. The Characteristics of Lahar in Merapi Volcano, Central Java as the Indicator of the Explosivity during Holocene. Jurnal Geologi Indonesia Vol 6 (2). Bandung: Badan Geologi.

[4] Purwantara, Suhadi. 2013. Resapan Buatan, Solusi Mengatasi Problema Air. Informasi Vol. 39 (1). Yogyakarta: FIS UNY

[5] Sutanto. 2013. Metode Penelitian Penginderaan Jauh. Yogyakarta: Ombak 